\title{
Ototoxicity of hydrocarbons present in gasoline: a literature review
}

\author{
Thais Fernandes da Silva ${ }^{(1)}$ \\ Daniela del Rosário Flores Rodrigues ${ }^{(1)}$ \\ Gilvânia Barreto Feitosa Coutinho(1) \\ Manuella Soares ${ }^{(1)}$ \\ Márcia Soalheiro de Almeida ${ }^{(1)}$ \\ Paula de Novaes Sarcinelli(1) \\ Rita de Cássia Oliveira da Costa Mattos ${ }^{(1)}$ \\ Ariane Leites Larentis ${ }^{(1)}$ \\ Giselle Goulart de Oliveira Matos ${ }^{(1)}$
}

Fundação Oswaldo Cruz, Centro de Estudos da Saúde do Trabalhador e Ecologia Humana, Manguinhos, Rio de Janeiro, Brasil.

Conflict of interest: Nonexistent

\section{(c) (i)}

Received on: August 11, 2017

Accepted on: November 21, 2017

Mailing Address:

Thaís Fernandes da Silva

CESTEH/ENSP/FIOCRUZ

Rua Galileu, 154 - Cachambi

CEP: 20785-070 - Rio de Janeiro, Rio de

Janeiro, Brasil

E-mail: tsilvafe@gmail.com

\section{ABSTRACT}

Purpose: to investigate the toxicity effects of major hydrocarbons present in gasoline on the auditory system and the related mechanisms of action.

Methods: a literature review between 2005 and 2015 was conducted using LILACS, MEDLINE and SciELO, by combining descriptors and their respective terms in Portuguese, English and Spanish.

Results: studies performed in humans and animals with hearing impairment, confirmed by morphological tests in rats, the influence of factors such as dose, duration, species and type of stimulus in hearing loss, and ineffective protection of workers by the threshold levels of exposure in the mixture of the compounds, were chosen.

Conclusion: toluene is regarded as an ototoxic compound that damages outer hair cells in the middle region of the cochlea, with evidence of interaction with noise. Ethylbenzene and xylenes can be considered potentially ototoxic based on the results of animal studies. No sufficient data were found on benzene to form a conclusion.

Keywords: Worker's Health; Occupational Health; Hearing Loss; Gasoline; Solvents 


\section{INTRODUCTION}

Hearing is a complex and sensitive function. Hearing processes occur both in the peripheral auditory system and in the central auditory nervous system (CANS) ${ }^{1}$. The peripheral system, composed of the external, middle and inner ears, in addition to the auditory nerve until its junction with the cochlear nucleus, is responsible for capturing, conducting, modifying, amplifying, analyzing, and transducing sound waves from the environment. The CANS, consisting of the brainstem, subcortical pathways, auditory cortex/temporal lobe, and corpus callosum, may involve central non-auditory areas $^{2}$ and is responsible for the neurological processing of acoustic information that enables the analysis and/or interpretation of the acoustic signals of speech.

This sensitive complex system can be damaged by several factors, including occupational hearing loss, where noise experienced in the work environment results in hearing loss. Noise-induced hearing loss alone is considered a work-related health problem of compulsory notification ${ }^{3}$, even today.

In 1984, the ototraumatic interaction between exposure to noise and solvents began to be discussed after the observation that sensorineural hearing loss in workers exposed to solvents was more pronounced than expected in the case of exposure to noise alone ${ }^{4}$.

Solvents are composed of hydrocarbons, which are molecules formed by carbon and hydrogen. In general, they are volatile and toxic organic compounds that have a high vapor pressure under normal conditions, to the point of volatizing significantly and entering the atmosphere. Some, known as aromatic hydrocarbons, have a pronounced odor due to delocalization of electrons in their cyclic structures ${ }^{5,6}$.

Fuels are important sources of aromatic hydrocarbons. Gasoline consists of a mixture of aromatic hydrocarbons in addition to other substances in low concentrations such as sulfur, oxygen, metals, and nitrogen ${ }^{7}$. This composition varies according to its use, origin, and petroleum refining processes. There is a predominance of hydrocarbons with 4 to 12 carbon atoms ${ }^{5,6}$. The main aromatic hydrocarbons present in gasoline are benzene, toluene, ethylbenzene, and xylene isomers, also known as $\mathrm{BTEX}^{8}$, benzene being the simplest and most common representative of these aromatics, both because of its composition and the fact that it is always present in mixtures. It is considered a highly toxic product, which can be absorbed by the human body, mainly by breathing and contact with the skin, and recognized as a group 1 human carcinogen by the International Agency for Research on Cancer ${ }^{9}$, with no safe exposure limits ${ }^{10}$.

The publication that marks the 10-year anniversary of the Benzene Agreement ${ }^{11}$ mentions hearing losses caused by this carcinogenic compound. These losses are considered chronic effects of exposure, with possible peripheral and central changes. Neurosensory hearing loss, tinnitus, vertigo (vestibular system in conjunction with the auditory system) and auditory processing difficulties are observed. The Agreement defines the need to use other audiological tests in addition to conventional tonal audiometry by air and bone and vocal audiometry for research, taking into account that these may not be sufficient for the diagnosis. It suggests tests such as immitanciometry, vestibular examination, otoacoustic emission, brainstem audiometry, and auditory processing tests and considers them important for obtaining complete information about the topodiagnosis of the lesion ${ }^{11}$.

In the Standards and Technical Manuals from the Ministry of Health, hearing impairments are also considered chronic effects of exposure and are included as part of the protocol for assessing damage in benzene-exposed individuals as item g, "other investigations: research on the central nervous system, otoneurological evaluation," which includes the issue of balance ${ }^{12}$.

In Brazil, the National Agency for Petroleum, Natural Gas, and Biofuels (ANP) is the body responsible for regulating and monitoring the quality of this fuel. The ANP specifies the two main types of gasoline marketed: type A, which is obtained directly from the refineries and is not allowed to be marketed at gas stations, and type $\mathrm{C}$, which is obtained from a mixture of type $\mathrm{A}$ gasoline and anhydrous ethyl alcohol, sold in retail outlets ${ }^{13}$. The type $\mathrm{C}$ gasolines, common or with additives, differ only by the presence of detergent additives, which act as dispersants of the dye. Commercial gasolines are not much different from refinery gasolines in BTEX levels ${ }^{14}$. The ANP Technical Regulation no. 05/2001, annex to resolution $309 / 2001^{3}$, specifies type $C$ gasoline with 25 $\pm 1 \%(\mathrm{v} / \mathrm{v})$ anhydrous ethyl alcohol and not more than $1 \%$ benzene and $45 \%$ aromatic compounds.

Therefore, gas station workers are exposed to a complex mixture of different chemicals/solvents in their working environment, including benzene, a carcinogenic compound, which has no safe limit of exposure ${ }^{10}$ and can cause hearing impairment ${ }^{11,12}$. 
Protection policies for workers have been studied regarding the mutagenic and carcinogenic actions of benzene ${ }^{10-12}$. However, with respect to hearing, only the need for assessment has been reported ${ }^{11,12}$. In order to contemplate hearing healthcare policies for workers dealing with fuels, it is necessary to know and understand the hearing losses caused by hydrocarbons, more specifically by BTEX.

Taking into account these identified aspects and the current policies to control the use and handling of benzene and other gasoline components, the objective of this study was to conduct a literature review on the deleterious effects related to the auditory system caused by the main hydrocarbons present in gasoline, and the respective toxic mechanisms.

\section{METHODS}

An exploratory study was performed in the form of a bibliographic review using a qualitative approach ${ }^{15}$ based on a scientific literature search of the databases SciELO, LILACS and MEDLINE from January 2005 to December 2015.

The search strategy included the use and the combination of the following established keywords and terms after looking at the Health Sciences DescriptorsDeCS and Medical Subject Headings (MESH): worker's health, occupational health, hearing loss, solvents, gasoline, and their respective terms in Portuguese, English, and Spanish. Resources that allowed expanding or specifying the search, called Boolean operators, were used with the aid of the advanced form of the Virtual Health Library. The following descriptors were analyzed in conjunction: health of the worker and the other descriptors and occupational health and the other descriptors. The publication period and the language were used as filters.

Initially, abstracts were read on an exploratory basis to identify texts that reported data on the combination of the mentioned descriptors followed by a selective reading to identify the material of interest to the study, an analytical reading to order and summarize the information to in accord with the proposed objective, and finally, an interpretative reading of the research data linking the significant data from proven theories ${ }^{15}$. Articles containing information on at least one of the four gasoline hydrocarbons known as BTEX were read in full and used.

The inclusion criteria were publication from January 2005 to December 2015 in SciELO, LILACS, and MEDLINE; publication in Portuguese, English, or Spanish; addressed the toxic effects of solvents on the auditory system, identified by the selected descriptors.

Of 20 bibliographical studies retrieved in this study, 15 studies were analyzed.

\section{LITERATURE REVIEW}

In this review, the results were divided into articles containing data on exposure to solvents and mixtures such as gasoline and those containing data on subsequent exposure to each of the hydrocarbons (benzene, toluene, ethylbenzene, and xylene isomers) separately, and in chronological order. The damage caused by exposure is manifested in the form of peripheral and/or central hearing difficulties. The results of the articles are summarized in a Figure 1. 


\begin{tabular}{|c|c|c|c|c|}
\hline Authors & $\begin{array}{c}\text { Type of study/ } \\
\text { design }\end{array}$ & Sample & Agents & Conclusions \\
\hline $\begin{array}{l}\text { Gagnaire and } \\
\text { Langlais, } \\
2005^{28}\end{array}$ & $\begin{array}{l}\text { Experimental, } \\
\text { chart }\end{array}$ & Animals & $\begin{array}{l}\text { Benzene, } \\
\text { ethylbenzene, } \\
\text { toluene, xylene }\end{array}$ & $\begin{array}{l}\text { Ethylbenzene was assessed as the most potent ototoxic solvent. } \\
\text { Morphological examinations showed an almost total loss in three } \\
\text { rows of OHC in the middle and apical regions of the cochlea. Inner } \\
\text { hair cell losses were observed, but they were not located in a specific } \\
\text { area of the cochlea. }\end{array}$ \\
\hline $\begin{array}{l}\text { Fuente and } \\
\text { McPherson, } \\
2007^{16}\end{array}$ & $\begin{array}{l}\text { Observational, } \\
\text { analytical, case- } \\
\text { control study }\end{array}$ & Humans & Toluene, xylene & $\begin{array}{l}\text { Central auditory processing disorder (CDPA). Significantly more } \\
\text { auditory complaints were found in listening situations in daily life } \\
\text { among exposed workers than among unexposed workers. }\end{array}$ \\
\hline $\begin{array}{l}\text { Vyscocil } \\
\text { et al., 2008 }\end{array}$ & Review article & $\begin{array}{c}\text { Animals and } \\
\text { humans }\end{array}$ & Ethylbenzene & $\begin{array}{l}\text { Concentrations below } 300 \mathrm{ppm} \text { ethylbenzene did not cause hearing } \\
\text { damage, but already showed changes of ciliated cells. The effect was } \\
\text { proportional to the dose, being capable of causing damage at lower } \\
\text { doses than those of other solvents. Benzene should be considered an } \\
\text { ototoxic agent given the evidence from animal studies. }\end{array}$ \\
\hline $\begin{array}{l}\text { Fuente, } \\
2010^{19}\end{array}$ & Literature review & Humans & Toluene, xylene & $\begin{array}{l}\text { All studies in the review suggest that the organic solvents are } \\
\text { associated with a central auditory dysfunction, because the studies } \\
\text { conducted in populations of workers exposed to these agents found } \\
\text { abnormalities in electrophysiological tests and central auditory } \\
\text { processing tests. Some studies have shown that such evidence may } \\
\text { be abnormal, in particular the electrophysiological tests, even when } \\
\text { the audiometric thresholds are within the limits of normality. }\end{array}$ \\
\hline $\begin{array}{c}\text { Augusto } \\
\text { et al., } 2012^{29}\end{array}$ & Literature review & Humans & Toluene & $\begin{array}{l}\text { The agents in the work environment and its effects were studied in an } \\
\text { isolated manner and the limits of tolerance of these do not consider } \\
\text { combined exposures. Workers must be part of the HLPP even when } \\
\text { exposed doses are below the recommended exposure limit. The } \\
\text { audiometric findings, due to ototoxicity from exposure to toluene, } \\
\text { feature similar audiograms to those of noise exposure. }\end{array}$ \\
\hline $\begin{array}{c}\text { Metwally } \\
\text { et al., } 2012^{20}\end{array}$ & $\begin{array}{l}\text { Observational, } \\
\text { analytical, case- } \\
\text { control study }\end{array}$ & Humans & Toluene, xylene & $\begin{array}{l}\text { Positive responses to peripheral hearing loss were induced by the } \\
\text { mixture of toluene and xylene with and without exposure to noise. A } \\
\text { higher prevalence of sensorineural hearing loss was found in workers } \\
\text { exposed to the combination of noise and solvents compared with } \\
\text { workers exposed only to noise, although both exposure levels were } \\
\text { within the allowed limits. A reassessment of the levels of exposure } \\
\text { limits is suggested owing to the synergistic action with potentiation } \\
\text { of hearing impairment. }\end{array}$ \\
\hline $\begin{array}{c}\text { Quevedo } \\
\text { et al., } 2012^{25}\end{array}$ & $\begin{array}{l}\text { Observational, } \\
\text { analytical, case- } \\
\text { control study }\end{array}$ & Humans & Gasoline & $\begin{array}{l}\text { No signs of change were found in the } \mathrm{OHC} \text { and the medial } \\
\text { olivocochlear system in gas station attendants. Results were contrary } \\
\text { to the literature, which reports abnormalities of OHC from exposure } \\
\text { to solvents. Note that the gas stations, unlike the industrial scenario, } \\
\text { are open occupational environments, with consequent dispersion of } \\
\text { possible ototoxic agents and consequent reduction of hearing losses. }\end{array}$ \\
\hline $\begin{array}{l}\text { Quevedo } \\
\text { et al., 201226 }\end{array}$ & $\begin{array}{c}\text { Observational, } \\
\text { descriptive; } \\
\text { cross-sectional } \\
\text { study }\end{array}$ & Humans & Gasoline & $\begin{array}{l}\text { Gas station attendants exposed to fuels for a minimum period of } 3 \\
\text { years, even with normal hearing thresholds, may undergo changes in } \\
\text { the central auditory system. }\end{array}$ \\
\hline $\begin{array}{c}\text { Vyscocil } \\
\text { et al., } 2012^{18}\end{array}$ & $\begin{array}{l}\text { Systematic } \\
\text { review article }\end{array}$ & $\begin{array}{c}\text { Animals and } \\
\text { humans }\end{array}$ & $\begin{array}{l}\text { Ethylbenzene, } \\
\text { toluene, } \\
\text { p-xylene }\end{array}$ & $\begin{array}{l}\text { Toluene is ototoxic, based on evidence found in studies conducted } \\
\text { in humans and animals; ethylbenzene and p-xylene are potentially } \\
\text { ototoxic drugs at concentrations relevant to patterns of labor } \\
\text { activities, with toluene being considered capable of exacerbating the } \\
\text { auditory dysfunction induced by noise, causing more severe hearing } \\
\text { loss than exposure to noise alone. }\end{array}$ \\
\hline $\begin{array}{l}\text { Tochetto } \\
\text { et al., } 2012^{27}\end{array}$ & $\begin{array}{l}\text { Observational, } \\
\text { analytical, case- } \\
\text { control study }\end{array}$ & Humans & Gasoline & $\begin{array}{l}\text { Higher average high-frequency audiometry thresholds were found } \\
\text { in the study group of gas station attendants at all frequencies } \\
\text { tested and acoustic reflexes are absent or exacerbated, indicating, } \\
\text { respectively, cochlear and central alteration. Exposure time was } \\
\text { directly proportional to the extent of the damage. }\end{array}$ \\
\hline
\end{tabular}




\begin{tabular}{|c|c|c|c|l|}
\hline Authors & $\begin{array}{c}\text { Type of study/ } \\
\text { design }\end{array}$ & Sample & Agents & Conclusions \\
\hline $\begin{array}{c}\text { Fuente } \text { et al.., } \\
2013^{21}\end{array}$ & $\begin{array}{c}\text { Observational, } \\
\text { analytical, case- } \\
\text { control study }\end{array}$ & Humans & Toluene, xylene & $\begin{array}{l}\text { The performance in daily activities is related to the functions of the } \\
\text { peripheral and central auditory system among workers exposed and } \\
\text { not exposed to solvents. }\end{array}$ \\
\hline $\begin{array}{c}\text { Fuente et al.., } \\
2013^{22} \\
\text { Observational, } \\
\text { analytical, case- } \\
\text { control study }\end{array}$ & Humans & Toluene, xylene & $\begin{array}{l}\text { Individuals exposed to solvents in the peripheral and central } \\
\text { auditory functions had worse results in a full battery of auditory } \\
\text { tests (assessment by pure tone and assessment of central auditory } \\
\text { potential and speech in noise). }\end{array}$ \\
\hline $\begin{array}{c}\text { Zhang et al., } \\
2013^{30}\end{array}$ & $\begin{array}{c}\text { Observational, } \\
\text { descriptive; } \\
\text { cross-sectional } \\
\text { study }\end{array}$ & Humans & Ethylbenzene & $\begin{array}{l}\text { Exposure to benzene may be associated with hearing loss, impaired } \\
\text { neurobehavioral function, and imbalance of neurotransmitters. }\end{array}$ \\
\hline $\begin{array}{c}\text { Lobato et al.., } \\
2014^{24} \\
\text { analytical, } \\
\text { retrospective } \\
\text { cohort }\end{array}$ & Humans & Solvents & $\begin{array}{c}\text { Positive responses of ototoxicity from solvents and noise were found } \\
\text { in a retrospective study in metal industry graphics. }\end{array}$ \\
\hline $\begin{array}{c}\text { Observational, } \\
\text { analytical, } \\
\text { retrospective } \\
\text { case-control } \\
\text { study }\end{array}$ & Humans & Benzene, & toluene, xylene & $\begin{array}{l}\text { Positive responses were found in the presence of auditory changes } \\
\text { with exposure to noise and to solvents through a case-control study } \\
\text { of bus and truck factory workers. }\end{array}$ \\
\hline
\end{tabular}

CAPD, central auditory processing disorder; OHC, outer hair cell; ppm, parts per million; HLPP, hearing loss prevention programs.

Figure 1. Summary of studies found in the literature about the deleterious effects of hydrocarbons in gasoline on the auditory system and its mechanisms, published from January 2005 to December 2015

\section{Exposure to solvents and mixtures}

Fuente and McPherson ${ }^{16}$ conducted an observational study on workers of a paint factory in Chile. Assessments of peripheral and central hearing were performed. Changes in or poor performance of auditory processing disorders were found in the exposed group of workers, compared with the occupationally non-exposed group. The study included 50 workers exposed to a mixture of organic solvents (xylene, toluene, and methyl-ethyl-ketone) and 50 unexposed workers, matched by age, sex, and education. Only workers with no history of ear infections, hypertension, renal failure, metabolic and neurological diseases, or alcoholism; with age between 18 and 55 years; and with a minimum of 2 years of exposure to solvents participated in this study. Subjects had normal hearing or sensorineural hearing loss and normal tympanometric findings. The concentrations of solvents in air and noise levels were measured. The toluene and xylene concentrations were 25.72 and $36.82 \mathrm{mg} / \mathrm{m}^{3}$, respectively. These concentrations are below the threshold limit values (TLVs) for 8 hours of work in Chile: 300 and 347 $\mathrm{mg} / \mathrm{m}^{3}$, respectively. Only workers exposed to noise levels below 85 dBNPS were included in the study.
All the workers underwent behavioral tests of noise auditory processing (Hearing in Noise Test), the digit dichotic test, filtered speech test, frequency pattern test (FPT), Random Gap Detection Test (RGDT), and the Self-Report of Performance in Situations of Daily Living (Amsterdam Inventory for Auditory Disability and Handicap). Workers exposed to solvents reported significantly more auditory complaints in listening situations in daily life than non-exposed workers, probably due to altered auditory processing. The authors concluded that because of the central changes, the sole use of tonal audiometry is insufficient to assess hearing in populations exposed to solvents.

Vyscocil et al. conducted two literature reviews on ototoxicity ${ }^{17,18}$. The first, in 2008, on ethylbenzene, aimed to verify the effects of low-level exposure of this compound on the auditory system and to investigate its relevance in professional environments. The other, in 2012, aimed to identify available data on the toxicity of various chemical compounds (toluene, ethylbenzene, xylene isomers, lead, and others) and to consider their relevance in the occupational setting. The authors identified 53 studies, seven with humans and 46 with experimental animals. Regarding the studies with humans, four were performed with noise along with 
occupational exposure to chemical compounds. Based on evidence from human and animal studies, the authors concluded that toluene is an ototoxic compound, that ethylbenzene and $p$-xylene are potentially ototoxic, and that toluene could exacerbate noiseinduced auditory dysfunction, causing more severe hearing loss than exposure to noise alone.

In a literature review, Fuente ${ }^{19}$ gathered data on the harmful effects of solvents on the CANS in humans and discussed the ototoxic and neurotoxic mechanisms and how to evaluate this pathology, emphasizing the need for both the evaluation of the CANS and the use of evidence with respect to early detection of solventinduced hearing loss. The author noted that the findings suggest that organic solvents are associated with central auditory dysfunction in studies conducted in populations of exposed workers with electrophysiological (short-, medium-, and long-latency evoked potentials) abnormalities, and in central auditory processing tests, using the filtered speech, temporal patterns, and dichotic stimulation tests. The author found that these tests may be abnormal, especially the electrophysiological tests, even when the audiometric thresholds are within the limits of normality.

In a retrospective case-control study, Metwally et al. ${ }^{20}$ analyzed three groups of workers in Egypt, matched by age and socioeconomic patterns and found a highly significant difference between the study groups regarding hearing impairment. Group 1 consisted of 70 workers exposed to noise during carpentry work, with a mean age of 44.1 years and an average exposure of 20.5 years; group 2 consisted of 93 workers exposed to noise and solvents (a mixture of xylene and toluene) from a paint factory, with an average age of 43.5 years and an average exposure of 18.4 years (both groups 1 and 2, exposed to 8 hours/day for 5 days/week); and group 3 consisted of 59 individuals from an administrative office, without exposure, with a mean age of 41.5 years. The workers of the three groups underwent a general clinical examination, blood pressure measurement, meatoscopy, and tonal audiometry, and environmental monitoring was conducted. The audiogram results showed a higher prevalence of sensorineural hearing loss in workers exposed to noise and solvents (43\%) compared with those exposed to noise alone (24.3\%), even though this latter group were exposed for longer amounts of time. The noise exposure levels $(\mathrm{dB})$ of group 1 were higher than those of group 2, although both were within the recommended limits. The levels of organic solvents were much lower than the levels recommended by the Egyptian Environmental Law ${ }^{20}$. The authors hypothesized that the high prevalence of hearing impairment in the study could be attributed to the warm and humid environment, which favors the formation of excessive wax and recurrent middle ear infections, resulting in ear blockage and hearing loss. They also observed that toluene was the major component that significantly affected conventional audiometric thresholds even within the recommended occupational exposure limits.

In 2007, Fuente et al. ${ }^{21}$ performed another observational study also using the Amsterdam Inventory for Auditory Disability and Handicap questionnaire and the RGDT, with the objective to compare performance of daily activities related to the functions of the peripheral and central auditory system among workers exposed and not exposed to solvents. They concluded that there is a relationship between exposure to solvents and the difficulties involved in these activities. A significant correlation was observed between the results of the questionnaire, the average of the binaural hearing thresholds, and the results of the RGDT. A total of 96 workers participated in the study, with 48 workers exposed to solvents and 48 unexposed workers, matched by education, age, and sex. The evaluation procedures included pure tone audiometry to evaluate the peripheral auditory system, RGDT to evaluate the CANS, and the Amsterdam Inventory for Auditory Disability and Handicap to evaluate, through selfassessment, performance of daily life activities that involve hearing.

In 2013, Fuente et al. ${ }^{22}$ conducted another observational study to investigate the association between solvent exposure and adverse effects on peripheral and central auditory function from a full battery of hearing tests. In addition to pure tone audiometry, they aimed to evaluate the central auditory potential and speech in noise. The sample included 72 workers exposed to solvents, mainly toluene and xylene, and 72 unexposed workers; all underwent pure tone audiometry, transiently evoked otoacoustic emissions, RGDT, and the Hearing in Noise Test. The variable noise levels were controlled owing to the exposure requirement of less than 85 dBNPS. Individuals exposed to solvents had worse results than the unexposed workers.

Unlu et al. ${ }^{23}$ found auditory alterations with exposure to noise and solvents in a case-control study with 469 workers from a bus and truck factory with a 12.7-year average exposure to benzene, toluene, xylene, tetrachlorethylene, and acetone and occupational exposure 
limits for chemical compounds and physical agents within the limits permitted by the American Conference of Governmental Industrial Hygienists (ACGIH). The values found for benzene, for example, were $1.86 \mathrm{mg} /$ $\mathrm{m}^{3}$ in the paint shop and $0.98 \mathrm{mg} / \mathrm{m}^{3}$ in the paint store, where $46 \mathrm{mg} / \mathrm{m}^{3}$ of this compound is allowed according to the ACGIH TLVs. It should be noted, however, that because benzene is a carcinogenic compound ${ }^{9}$, there is no safe limit for exposure. In this study, the authors collected blood samples from individuals exposed to solvents; auditory measures were conducted for all the participants of the study using tonal audiometry by airway and by bone; noise testing was conducted with findings below $85 \mathrm{dBNA}$; and the presence of the solvents was determined by collecting samples in sealed glass adsorption tubes during one work shift, with the samples analyzed by gas chromatography. The authors suggest that high-frequency audiometry may be the most appropriate method to evaluate solventinduced ototoxicity and that solvents can cause hearing damage when mixed, even if their individual indices are within the limits allowed by regulatory agencies.

Lobato et al. ${ }^{24}$ found positive associations for the ototoxicity of solvents (aromatic hydrocarbons, toluene, xylene, turpentine, oils, greases, lead, chromates, and molybdates) in a retrospective observational study conducted in the graphic materials industry, with the study population divided into four groups: a group exposed to noise only, composed of 42 workers exposed to 85 to $93 \mathrm{dBA}$; a group exposed to noise and solvent, composed of 57 workers simultaneously exposed to noise from 88 to $98 \mathrm{dBA}$ and solvents; a noise control group; and a noise and solvent control group. Data from the control groups were obtained from the database of the Audiology Department of the University of Tuiuti, Paraná, and were grouped by age and sex. In the study, women were less susceptible than men when exposed only to noise, and the age group of 40 to 49 years presented significantly worse responses than the control group in the auditory thresholds of the simultaneous exposure group to the noise and solvents.

\section{Exposure to Gasoline}

Quevedo et al. ${ }^{25}$ conducted an observational study with 18 gas station attendants, with normal hearing, from three gas stations in the city of Santa Maria, in Rio Grande do Sul. The study evaluated the peripheral auditory system using the Transient Otoacoustic Emissions test, which verifies the operation of the outer hair cells (OHCs). No signs of early changes were found in the OHCs and the medial olivocochlear system of individuals with normal hearing. The authors reported that their results are in contrast to the literature, which indicates that alterations of $\mathrm{OHCs}$ occur after exposure to solvents. They pointed out that the gas stations, in comparison to the different industrial environments, are open occupational environments with dispersion of the possible ototoxic agents and consequent reduction of hearing losses.

In another study, Quevedo et al. ${ }^{26}$ used electrophysiologic testing of brainstem auditory evoked potentials (BAEPs), which evaluates the CANS, in the same group of gas station attendants from the study cited above, but with the addition of three individuals in the sample for a total of 21 gas station attendants. The researchers concluded that gas station attendants exposed to fuels for a minimum of 3 years, even with normal hearing thresholds, may undergo changes in their CANS, due to the statistically significant increase of absolute latencies and interpeak intervals of the interaural potential differences (BAEPs).

With the same study sample described previously (i.e., 21 gas station attendants), Tochetto et al. ${ }^{27}$ conducted another observational study of highfrequency audiometry and acoustic reflex tests. The authors observed higher mean upper-threshold audiometry thresholds in the studied group at all tested frequencies and absent or exacerbated acoustic reflexes, indicating, respectively, cochlear (peripheral) and central alterations. They reported that the exposure time was directly proportional to the extent of the damage.

\section{Exposure to Benzene}

Benzene did not cause significant loss of hair cells in an experimental study in rats conducted by Gagnaire and Langlais ${ }^{28}$ to compare the ototoxic potential of 21 separately tested aromatic solvents, some of which are present in gasoline and described later. Solvents were administered by oral gavage (nasogastric tube) for 5 days/week for 2 weeks. Ototoxicity was assessed using a cochlear morphological investigation to quantify the number of cells lost (cytocochleogram). The mice received $8.47 \mathrm{mmol} / \mathrm{kg} /$ day of benzene, a dose chosen based on toluene studies, which showed loss of OHCs without loss of body weight. Eight of the 21 aromatic solvents studied showed ototoxic properties, characterized by the outcome (ethylbenzene, styrene, and allylbenzene being the most ototoxic; a-methylstyrene 
having the least ototoxic potential; and toluene, $p$-xylene, $n$-propylbenzene, and trans- $\beta$-methylstyrene having an intermediate ototoxic potential).

No further studies on the ototoxicity of this hydrocarbon alone were found, but the studies on benzene emphasize its carcinogenicity.

\section{Exposure to Toluene}

In the experimental study of Gagnaire and Langlais ${ }^{28}$ in rats, described previously, with 21 aromatic compounds, toluene displayed an intermediate ototoxic potential. The authors defined intermediate ototoxic potential as damage occurring in the three rows of OHCs in the middle region of the cochlea. $\mathrm{A}$ lower ototoxic potential was considered when there were partial losses of $\mathrm{OHCs}$ in the middle region of the cochlea, as in the case of a-methylbenzene, which caused cell loss in the third row of OHCs. The highest ototoxic potential was defined as damage resulting in almost total loss in the three rows of OHCs, in the middle and apical parts of the cochlea.

In a literature review, Vyskocil et al. ${ }^{18}$ classified toluene as an ototoxic agent and called for more human studies to support the evidence, since they are less numerous and based on cross-sectional and non-experimental studies such as in studies experimental animals. The authors identified 53 studies, 46 with guinea pigs and seven with occupational exposure. Concerning studies of occupational exposure, four were performed with the presence of noise concomitant to solvent exposure, two with the same sample, and three in the absence of noise. Of these, five studies confirmed the ototoxicity of toluene and two linked hearing impairment to dose. The authors reported that electrophysiological tests demonstrated changes in the human auditory nervous system before the occurrence of clinical signs and that the lowest observed adverse effect level (LOAEL) for exposure should be greater than $50 \mathrm{ppm}$. The authors concluded that permanent damage to the $\mathrm{OHCs}$ on exposure to toluene, including losses (proven by morphological examinations), can be progressive even after the end of exposure. Based on the studies with rats described in the literature, the authors concluded that there was a higher incidence of hearing loss at medium frequencies; impairment of reflex protective activity, and an influence of factors such as concentrations and duration of exposure on loss of auditory sensitivity. The daily concentration was presented as more important than the total exposure time. The authors mentioned the difficulty of some studies in conducting an evaluation of noise alone, even opting for oral administration of toluene. These authors describe that the LOAEL for toluene ototoxicity in rats is 700-1500 ppm. Through four revised studies, Vyskocil et al. ${ }^{18}$ reported that the auditory pathway does not appear to be damaged. These authors also verified that hearing damage depends on the species, since two of three studies using guinea pigs showed negative responses to toluene ototoxicity with a LOAEL between 600 and 1000 ppm and reported only one study in chinchillas, with a LOAEL of 100 ppm, with a negative response. Of the six studies in guinea pigs with exposure to toluene and noise, five suggested additive or synergic cochlear damage. The additive effect is higher than the sum of the ototoxic effects isolated for solvents and for noise-induced hearing loss when noise is presented after exposure to toluene. After evaluating the various studies of exposure to toluene, Vyskocil et al. ${ }^{18}$ concluded that there is convincing evidence of ototoxic interaction after combined exposure of toluene and noise in workers and animals.

Augusto et al. ${ }^{29}$ conducted a literature review with the objective of comparing findings showing that workers exposed simultaneously to noise and solvents were most likely to develop a hearing loss of peripheral origin. They concluded that the audiometric findings of ototoxicity due to exposure to toluene present similar audiograms to those due to noise exposure. They concluded by stating that the tests should be more thorough, and all workers should be part of a hearing prevention program, even those exposed to lower doses than the recommended exposure limit, because occupational exposure and their effects do not take into account the tolerance limits for combined exposures.

\section{Exposure to Ethylbenzene}

In the previously described experimental study of Gagnaire and Langlais ${ }^{28}$ in rats, ethylbenzene was considered the most potent ototoxic compound. Morphological exams, performed 8 weeks after the end of exposure to ethylbenzene, showed almost total loss in the three rows of OHCs in the middle and apical regions of the cochlea, with loss of the basal part in approximately $50 \%$ of the animals. In addition, in some animals, loss of inner hair cells was also observed, but not localized to a specific area of the cochlea.

In the review on ethylbenzene by Vyskocil et al. ${ }^{17}$, seven animal studies were identified, but there was no study of occupational exposure. Furthermore, no occupational exposure studies were found in the 
review of Vyskocil et al. ${ }^{18}$ on the ototoxicity of chemical compounds, where six studies on isolated exposure of animals to ethylbenzene were reported. Susceptibility to ethylbenzene is species-dependent because it damages the auditory system of rats but does not alter that of guinea pigs. The damage occurs in the OHCs of the cochlea in the middle region. Owing to the evidence from animal studies, Vyskocil et al. ${ }^{17,18}$ recommended considering ethylbenzene as a possible ototoxic agent. They concluded, however, that new studies with sufficient data on the exposure of individual workers to ethylbenzene are necessary for a definitive conclusion and verification of an interaction with noise.

Another approach on the exposure only to ethylbenzene was discussed by Zhang et al. ${ }^{30}$ in a study on petrochemical workers. These authors concluded that exposure to this compound may be associated with hearing loss, impaired neurobehavioral function, and an imbalance of neurotransmitters. In their study, four groups composed of 246 and 307 workers from two petrochemical plants exposed to both ethylbenzene and noise were evaluated; 290 workers from a power station plant exposed to noise; and 327 office workers as a control group. Blood was analyzed using chromatography, tonal audiometry was conducted, and neurobehavioral function was evaluated.

\section{Exposure to Xylenes}

An intermediate ototoxic potential was displayed by $p$-xylene, with few losses of OHCs in the apical region of the cochlea. However, $m$-xylene and $o$-xylene did not cause $\mathrm{OHC}$ loss, according to experiments with rats conducted by Gagnaire and Langlais ${ }^{28}$.

Vyskocil et al..$^{18}$ identified only one study of occupational exposure to xylenes where no ototoxic effects were found after short-term exposure. The review showed that, in rats, xylene affects auditory function. In the review, no studies on the ototoxic interaction between xylenes and noise were identified and there are no reports on the topodiagnosis of auditory lesions caused by exposure to these compounds. Despite the lack of studies, Vyskocil et al. ${ }^{18}$ recommended considering $p$-xylene and, consequently, a mixture of xylene isomers, as possibly ototoxic, owing to the animal studies.

The physiological mechanism underlying the damage to the auditory system from solvents and the site most susceptible to injury, as well as other chemical products, was not known until $2001^{31}$. The limitations on this knowledge were caused mainly by the scarcity of studies of solvent ototoxicity and the few studies in humans, especially with regard to the location of the lesion $^{17,18}$.

The analysis of the articles in this study allowed us to have an initial idea of the impact in this setting, which has changed owing to the observational studies of exposure to solvents and of the combined exposure of noises and solvents. Observational studies combined with experimental studies in experimental animals allowed us to assess causality and reach more reliable conclusions.

In the late 1980s and early 1990s, toluene was suspected to cause structural damage to the stereocilia and/or the membranes of the cochlear hair cells, increasing vulnerability to noise ${ }^{18}$. Currently, ototoxicity is believed to be mainly characterized by loss of $\mathrm{OHCs}$ on the basis of morphological examinations of the cochlea of experimental animals ${ }^{18,28}$. Morphological analyses identified medium-frequency $(16-29 \mathrm{kHz})$ and high-frequency cochlear regions as the location of cochlear toxicity ${ }^{18,28}$. Damage to the inner hair cells can be added to the OHCs when the dose is high ${ }^{18}$ or when the xenobiotic substance has great ototoxic potential, as is the case of ethylbenzene described in the results found in this review ${ }^{28}$.

As no changes were observed in BAEPs due to solvent exposure (studies with rats and morphological examinations showed loss of cochlear cells), it can be stated that the auditory damage is not localized in the central auditory pathway. However, studies have shown alterations in BAEP responses in human studies, before the occurrence of clinical signs, upon chronic exposure to toluene ${ }^{18}$. These changes in electrophysiological tests, regardless of hearing damage, suggest functional impairment.

The sensitivity of hair cells to the toxicity of solvents can be explained by toxicokinetics and toxicodynamics, since these cells are sensory cells, with high levels of lipids and the solvents are liposoluble ${ }^{32}$. However, this relationship between the degree of ototoxicity and the lipophilic properties of the ototoxic agents is not always observed, which could suggest the hypothesis that some structural restriction would be essential to induce ototoxicity, such as the difference in the composition and chemical structure of xenobiotics ${ }^{28}$.

The daily concentration and duration of exposure to solvents/xenobiotics influence hearing loss. The toxic effect tends to be proportional to the dose and dependent on the chemical product. Ototoxicity may 
not cease even after the end of exposure. Toluene, for example, causes progressive hearing loss $^{18}$.

The species also influences the effect of the solvent with studies showing that guinea pigs are little affected by benzene and toluene ${ }^{16,17}$ and that toluene is not ototoxic in chinchillas ${ }^{18}$, which can call into question the significance to humans of studies in rats.

For some authors, the limits of exposure to solvents recommended in the standards are not sufficient to protect workers from hearing losses when these compounds are mixed ${ }^{20,23}$. In addition, there is a consensus that a combined exposure to noise and solvents is more ototoxic than exposure only to noise ${ }^{17,18,20,23,24}$. Some authors suggest that the limits recommended by laws and regulations should be reevaluated owing to the synergistic effects of the different solvents with respect to the potential to cause hearing impairment ${ }^{20}$.

According to the European Agency for Safety and Health at Work ${ }^{33}$, toluene, ethylbenzene, and $p$-xylene are compounds with good evidence of ototoxicity. Toluene induced a significant threshold change at a concentration of 1500 ppm (6 hours/day, 5 days/week, for 4 weeks) and ethylbenzene at 400 ppm (8 hours/ day for 5 days). Toluene has a current time-weighted average exposure value of $50 \mathrm{ppm}$ in Canada. Ethylbenzene was considered the most potent ototoxic agent because it causes damage at lower concentrations than other solvents ${ }^{17,18,28}$. This review found only two studies discussing exposure to benzene: one in experimental animals and another case-control study of occupational exposure. The latter, performed with a mixture of solvents, does not permit causality. The ototoxic effect found in the occupational exposure study may be attributed to other hydrocarbons.

The studies analyzed show a concern with the evaluation of occupational hearing loss. Current studies point to high-frequency audiometry as the best way of evaluating the effects of solvent-induced peripheral hearing loss on workers exposed to the solvents analyzed ${ }^{23,26}$, as it indicates the occurrence of early changes in the auditory system ${ }^{26}$. However, individuals exposed to solvents may acquire a central auditory processing disorder, a change in auditory function, for which the use of tonal audiometry alone is considered insufficient ${ }^{16,19}$. This information confirms what was stated in the publication commemorating the 10-year anniversary of the Benzene Agreement ${ }^{11}$. For this type of evaluation, auditory processing behavioral tests are being used, such as the temporal resolution test
RGDT $^{21}$. By 2013, there were several studies using pure tone evaluation. However, studies using central hearing measurements were still scarce, and still more scarce were studies using measures of OHCs and central hearing in the same sample ${ }^{22}$.

Despite the evidence of the ototoxicity of the compounds present in gasoline, the perspective identified in this literature review points to the need for further studies to prove hearing losses caused by solvents present at gas stations. The particularities of these solvent exposure environments can generate biases for the analysis. Studies of solvent-exposed workers in industries may result in different data from those performed at gas stations, as these are open occupational environments, where solvents may be less concentrated in the air, reducing inhalation and absorption of the agents, and may generate only a minor consequence for the auditory system ${ }^{26}$.

On account of this particularity, further studies are needed that address the working environments in gas stations and more experimental studies of the benzene content in gasoline, given that it is a proven carcinogen and does not have a safe limit of exposure ${ }^{10}$, regardless of the evidence of ototoxicity. Further studies involving the evaluation of central auditory processing are also indicated, with the purpose of understanding the actual scenario of gas station workplaces and correlating it with the health of exposed workers.

\section{CONCLUSION}

According to the articles selected in this review, toluene is considered ototoxic and thought to damage the $\mathrm{OHC}$ in the middle region of the cochlea, with evidence of an interaction with noise, whereas ethylbenzene and xylenes can be considered potentially ototoxic according to animal studies, in which lesions/ losses of $\mathrm{OHC}$ have also been observed. However, although benzene is a proven carcinogen with no safe exposure limit, it is not possible to draw conclusions about its ototoxic potential owing to the lack of studies on these effects.

\section{REFERENCES}

1. Musiek FE. Frequency (pitch) and duration pattern tests. J Am Acad Audiol. 1994;5(4):265-8.

2. American Speech-Language-Hearing Association (ASHA). Central Auditory Processing: current status of research and implication clinical pratice. 5th ed. 1996. p. 41-52. 
3. Brasil - Ministério da Saúde. Portaria 777/2004. Disponivel em: https://www.google.fr/search?q=M inist\%C3\%A9rio+da+Sa\%C3\%BAde.+PORTARIA. $+777+\mathrm{Apr}+28 \% 2 \mathrm{C}+2004 . \&$ oq $=$ Minist $\%$ C3\%A9rio + da+Sa\%C3\%BAde. +PORTARIA. + 777+Apr+28 $\% 2 \mathrm{C}+2004 . \&$ aqs $=$ chrome..69i57.574722j0j9\&sour ceid $=$ chrome $\&$ ie $=$ UTF- 8

4. Barregård L, Axelsson A. Is there an ototraumatic interaction between noise and solvents? Int $\mathrm{J}$ Audiol. 1984;13(3):151-5.

5. Wiedemann LS, d'Avila LA, Azevedo D de A. Brazilian gasoline quality: study of adulteration by statistical analysis and gas chromatography. J Braz Chem Soc. 2005;16(2):139-46.

6. Flumignan DL, Anaia GC, Ferreira FO, Tininis AG, de Oliveira JE. Screening brazilian automotive gasoline quality through quantification of saturated hydrocarbons and anhydrous ethanol by gas chromatography and exploratory data analysis. Chromatographia. 2007;65(9):617-23.

7. Moreira SL, d'Avila AL, Azevedo AD. Automotive gasoline quality analysis by gas chromatography: Study of Adulteration. Chromatographia. 2003;58(7):501-5.

8. Periago JF, Zambudio A, Prado C. Evaluation of environmental levels of aromatic hydrocarbons in gasoline service stations by gas chromatography. $J$ Chromatogr A. 1997;778(1-2):263-8.

9. International Agency for Research on Cancer, editor. Some industrial chemicals and dyestuffs: this publication represents the views and expert opinions of an IARC Working Group on the evaluation of the carcinogenic risk of chemicals to humans which met in Lyon, 13 - 20 October 1981 [Internet]. Lyon: International Agency for Research on Cancer; 1982. 416 p. (IARC Monographs on evaluation of the carcinogenic risk of chemicals to humans). Available from: https://monographs.iarc. fr/ENG/Monographs/vol1-42/mono29.pdf

10. Mendes M, Machado JMH, Durand A, CostaAmaral IC, Valente D, Gonçalves ES et al. Normas ocupacionais do benzeno: uma abordagem sobre o risco e exposição nos postos de revenda de combustíveis. Rev Bras Saúde Ocup. 2017;42(supl 1):e3s.

11. Arcuri ASA, Cardoso LMN. Acordo e legislação sobre o benzeno-10 anos [Internet]. São Paulo: Fundacentro; 2005. 127 p. Available from: http://www.fundacentro.gov.br/biblioteca/ biblioteca-digital/publicacao/detalhe/2013/3/ acordo-e-legislacao-sobre-o-benzeno-10-anos

12. Brasil - Ministério da Saúde. Secretaria de Atenção à Saúde. Departamento de Ações Programáticas Estratégicas. Risco químico: atenção à saúde dos trabalhadores expostos ao benzeno. Brasília: Ministério da Saúde; 2006.

13. Brasil - Agência Nacional do Petróleo, Gás Natural e Biocombustíveis (APN). Portaria ANP. 309/2001. Disponivel em: Agência Nacional do Petróleo, Gás Natural e Biocombustíveis (APN). Portaria ANP. 309 Dec 27, 2001.

14. Silva FL do N, Santos Jr. JR dos, Moita Neto JM, Silva RLG do NP da, Flumignan DL, Oliveira JE de. Determinação de benzeno, tolueno, etilbenzeno e xilenos em gasolina comercializada nos postos do estado do Piauí. Quím Nova. 2009;32(1):56-60.

15. Gil AC. Como elaborar projetos de pesquisa. $4^{a}$ Edição. Editora Atlas, São Paulo, 2002.

16. Fuente A, McPherson B. Central auditory processing effects induced by solvent exposure. Int J Occup Med Environ Health [Internet]. 2007 Jan 1 [cited 2016 Aug 26];20(3). Available from: http:// www.degruyter.com/view/j/ijmh.2007.20.issue-3/ v10001-007-0030-4/v10001-007-0030-4.xml

17. Vyskocil A, Leroux T, Truchon G, Lemay F, Gendron M, Gagnon F et al. Ethyl benzene should be considered ototoxic at occupationally relevant exposure concentrations. Toxicol Ind Health. 2008;24(4):241-6.

18. Vyskocil A, Truchon G, Leroux T, Lemay F, Gendron M, Gagnon F et al. A weight of evidence approach for the assessment of the ototoxic potential of industrial chemicals. Toxicol Ind Health. 2012;28(9):796-819.

19. Fuente CA. Solvent exposure and central auditory dysfunction: A literature review on the scientific evidence. Rev Otorrinolaringol Cir Cabeza Cuello. 2010;70(3):273-82.

20. Metwally FM, Aziz HM, Mahdy-Abdallah $H$, EIGelil KSA, El-Tahlawy EM. Effect of combined occupational exposure to noise and organic solvents on hearing. Toxicol Ind Health. 2012;28(10):901-7.

21. Fuente A, McPhersonY B, Hormazabal $X$. Self-reported hearing performance in workers exposed to solvents. Rev Saúde Pública. 2013;47(1):86-93. 
22. Fuente A, McPherson B, Hickson L. Auditory dysfunction associated with solvent exposure. BMC Public Health. 2013;13(1):1.

23. Unlu I, Kesici GG, Basturk A, Kos M, Yilmaz OH. A comparison of the effects of solvent and noise exposure on hearing, together and separately. Noise Health. 2014;16(73):410-5.

24. Lobato D, Lacerda A, Gonçalves C, Coifman H. Auditory effects of exposure to noise and solvents: a comparative study. Int Arch Otorhinolaryngol. 2014;18(2):136-41.

25. Quevedo L, Tochetto T, Siqueira M. Cochlear condition and olivocochlear system of gas station attendants exposed to organic solvents. Arq Int Otorrinolaringol. 2012;16(1):50-6.

26. Quevedo L, Tochetto T, Siqueira MA, Machado MS. Auditory brainstem response in gas station attendants. Braz $\mathrm{J}$ Otorhinolaryngol. 2012;78(6):63-8.

27. Tochetto TM, Quevedo L, Siqueira MA. Hearing conditions of gas stations attendants. Rev. CEFAC. 2013;15(5):1137-47.

28. Gagnaire F, Langlais C. Relative ototoxicity of 21 aromatic solvents. Arch Toxicol. 2005;79(6):346-54.

29. Augusto L, Kulay L, Franco E. Audition and exhibition to toluene - a contribution for the them. Int Arch Otorhinolaryngol [Internet]. 2012 May [cited 2016 Aug 26];16(2). Available from: http://www. internationalarchivesent.org/conteudo/acervo_eng. asp?id $=859$

30. Zhang M, Wang Y, Wang Q, Yang D, Zhang J, Wang $\mathrm{F}$ et al. Ethylbenzene-induced hearing loss, neurobehavioral function, and neurotransmitter alterations in petrochemical workers: J Occup Environ Med. 2013;55(9):1001-6.

31. Souza MMN de, Bernardi AP de A. Ototoxicidade dos produtos químicos: enfoque ocupacional. Rev. CEFAC. 2001;3:95-102.

32. Sułkowski WJ, Kowalska S, Matyja W, Guzek W, Wesołowski W, Szymczak W et al. Effects of occupational exposure to a mixture of solvents on the inner ear: a field study. Int $\mathrm{J}$ Occup Med Environ Health. 2002;15(3):247-56.

33. Campo P, Maguin K, Gabriel S, Möller A, Nies E, Solé Gómez MD et al. Combined exposure to noise and ototoxic substances [Internet]. Luxembourg: Publications Office; 2009 [cited 2016 Sep 5]. Available from: http://bookshop.europa.eu/uri?targ et=EUB:NOTICE:TE8009996:EN:HTML 